\title{
Modern Movement Mediations: Brazilian Modernism and the Identity of Post-War Architecture in Pretoria, South Africa.
}

\author{
BARKER, Arthur ${ }^{1}$ \\ ${ }^{1}$ Faculty of Engineering, the Built Environment and Information Technology, \\ University of Pretoria, Pretoria, South Africa.
}

\section{Resumo}

A arquitetura brasileira de Oscar Niemeyer inspirou o desenho de um grande número de construções sulafricanas. Este artigo contextualiza as mediações do movimento moderno e aponta similaridades em aproximação com a identidade, contexto e uma série de eficiências a partir de uma comparação do prédio do Ministério da Educação do Rio de Janeiro, de Niemeyer, 1945 e o prédio do Meat Board de Pretoria, de Helmut Stauch, 1952.

Palavras-Chave: Movimento Moderno, Brasil Builds, Hellmut Stauch, Oscar Niemeyer.

\begin{abstract}
The brazilian architecture of Oscar Niemeyer inspired the design of a number of South African buildings. This article will contextualise modern movement mediations and will highlight similarities in approach to identity, context and a range of efficiencies through a comparison of Oscar Niemeyer's 1945 Ministry of Education and Health Building in Rio de Janeiro and Helmut Stauch's 1952 Meat Board Building in Pretoria.
\end{abstract}

Key-Words: Modern Movement, Brazil Builds, Hellmut Stauch, Oscar Niemeyer. 

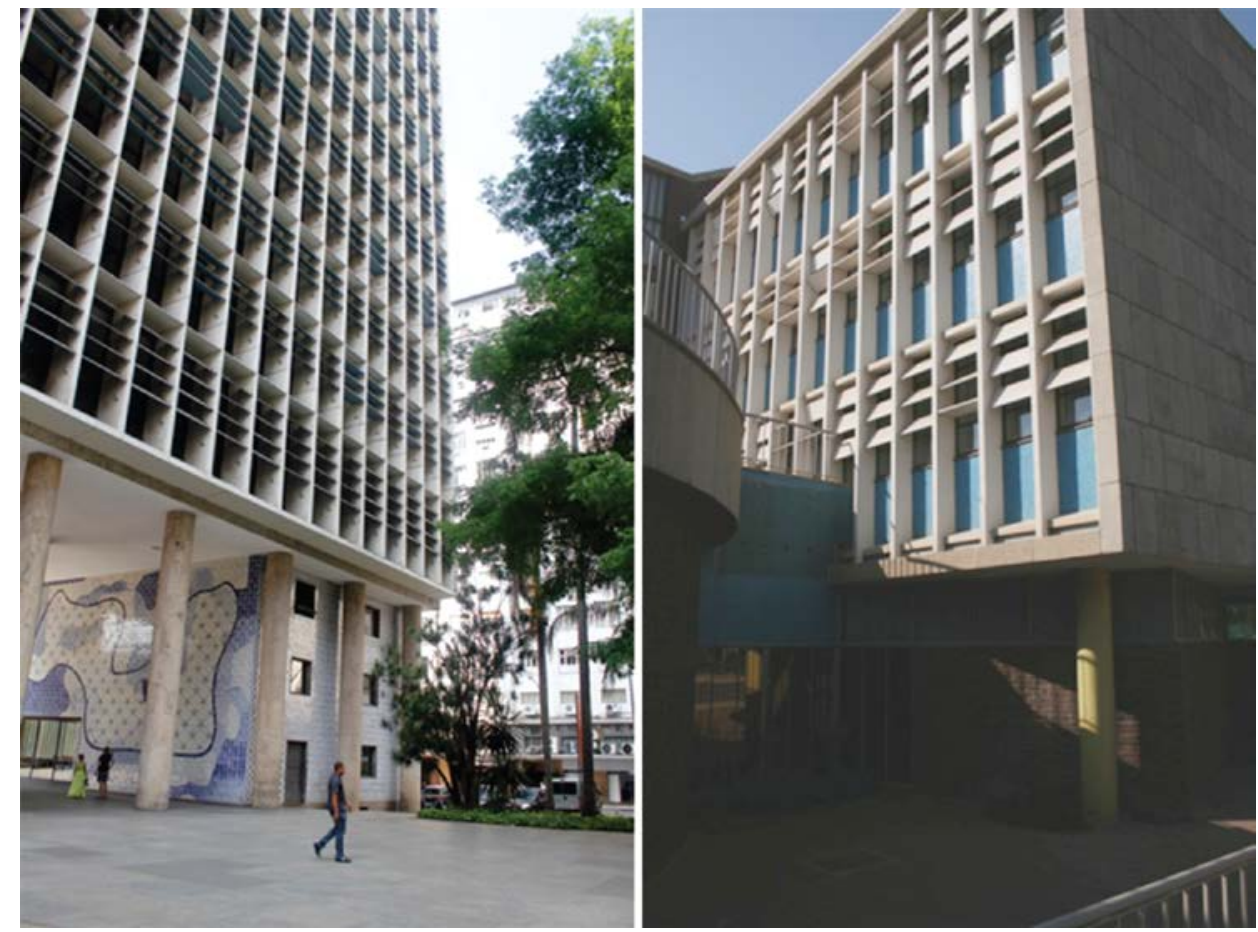

Figure 1. Left: Niemeyer's Ministry of Education and Health Building in Rio de Janeiro (Author, 2012). Right: Stauch's Meat Board Building in Pretoria, South Africa (Author, 2008).

\section{Introduction}

$7161 \mathrm{~km}$ east of Brasilia, in the reading room of the Department of Architecture at the University of Pretoria in South Africa, stands a scale model (see Fig. 2) of the Meat Board Building designed by a German immigrant to the Union of South Africa, Hellmut Wilhelm Ernst Stauch (19101970). It was the first building to be built in this country that was influenced by the regional modernism of Brazil, aptly suited to local climatic conditions and spatial and constructional efficiencies.

"The book Brazil Builds ${ }^{1}$ was to post-war students in Pretoria what Vers une Architecture had been to Martienssen's generation ${ }^{2}$ in Johannesburg, and in the years to come its influence left an enduring mark on the architecture of Pretoria. Nikolaus Pevsner later called Johannesburg 'a little Brazil',' but the description may have suited Pretoria even better" (SILVERMAN, 1999, p. 229).

The inheritances of post-war Pretoria buildings

\footnotetext{
1 The Brazil Builds exhibition was launched in 1943, the same year that the Department of Architecture was formed at the University of Pretoria.

${ }^{2}$ See section in this article called "Modern Movements in the Union of South Africa".
}

were also the result of a search for a new architectural identity after the estalishment of a Nationalist Government ${ }^{3}$ under D.F. Malan (18741959) in $1948^{4}$.

This architectural-historical article will provide a glimpse into the influence of Brazilian late Modern Movement architecture on that in the Union of South Africa (1910-1961) through a comparative analysis of Oscar Niemeyer's (1907-2012) Ministry of Education and Health Building (1936$1945)^{5}$ in Rio de Janeiro and Hellmut Stauch's Meat Board Building in Pretoria (1952) (see Fig. 1). Firstly mediations of the Modern Movement will be described to unpack the dissemination of its canon and various adaptations in the world, concluding with a South African mediation. Then direct and indirect linkages with late Brazilian Modern Movement architecture will be sketched.

\footnotetext{
${ }^{3}$ This was the start of the policies of Apartheid founded on the idea of separate development of race groups under white domination

${ }^{4} 1948$ was also the first graduation year of the first group of architectural students at the University of Pretoria, a school, started in 1943 that developed a contextual design focus premised on appropriate climatic responses and spatial and technological efficiencies.

${ }^{5}$ Also known as Gustavo Capanema Palace.
} 
Finally, the adoption of a climatically suitable and spatially efficient architecture will be described to highlight the development of a post Second World War Pretoria architectural identity.

\section{Modern Movements}

The first Modern Movement was the most coherent (albeit dogmatic) approach to the pressing issues of the time. At its core was the pursuit of the new and a reaction against the stagnant use of tradition. It mediated, amongst other concerns, between the modern and the classical, autocracy and democracy, and craft and industrialization. The movement expressed a programmatic and pastoral view of modernity (HEYNEN, 1999, p. 11-14). Architects like Le Corbusier (1887-1965), Mies van der Rohe (1886-1969) and Walter Gropius (1883-1969) held common beliefs about the human condition that bordered on a social utopianism (JENCKS, 1985 , p. 31). It was a period of idealism and architects believed that a new social order could be established through the advances of technology. In architectural terms this was exemplified by the possibilities inherent in new technologies like reinforced concrete, along with Le Corbusier's 'five points for a new architecture' and 'house as machine' metaphor. The heroic period of modern architecture had established itself through canon (BARKER, 2012, p. 75).

The second period of the Modern Movement (BARKER, 2012, p. 76) is defined by Joedicke (1969, p. 16) as spanning a period of ten years from 1930 to 1939, that is, in Europe until the Second World War began. He suggests that modern architecture had spread across Europe in variations influenced by climate, topography and tradition. The expressions of modernity were certainly still programmatic, but after the CIAM conference of 1928 St. John Wilson (2007) argued that another tradition of Modern architecture was formed, as an inner critique of pastoral Modernity.

The third period of the Modern Movement can be said to have developed after the Second World War which was followed by a period of physical, social and economic reconstruction. Modernity shifted from a programmatic bias to a transitory one. The CIAM meeting of 1947 resulted in a reconsideration of its original orthodox position, arguing for an architecture that would meet the material and emotional needs of society (PRINSLOO, 2000, p. 96). The idealist phase of the Modern Movement was over and as Ghirado (1996) and Curtis (1996) argue, universal prototypes began to be misapplied while revolution was replaced with capitalism.

In Europe this tendency had already reared its head in the 1930s, with the transmigration of work of architects like Alvar Aalto (1898-1976). But the major shift occurred in work outside Europe, particularly in developing countries in South America and Africa. These regions were exposed to Modern Movement tendencies through the European education of their architects, the relocation of architects, extended trade, and the dissemination of publications such as those of the Museum of Modern Art $^{6}$. International Style architecture was easily adopted by countries that saw it as a way of creating a new tradition that severed the connection with colonial powers, or even as a reaction against restrictive regional tendencies (CURTIS, 1996, p. 396).

The cosmopoliotan population of Brazil, mainly from Italy, then Spain and Portugal (GERNEKE, 1998, p. 202) brought Modern Art to the country but even before the advent of the Vargas government in 1930 there were Brazilian experiments in modern architecture. From modest beginnings the movement, happening to coincide with a building boom, spread like brushfire (GOODWIN, 1943a, p. 81 and 1943b p. 10).

A direct relationship with France through Le Corbusier and his collaboration with Brazilian architects, the overseas training of architects, foreign study, travel and publications furthered Modern Movement influences. One of the first Modern Movement inspired architects in Brazil was Lúcio Costa (1902-1988), who was born in France, educated in England and Switzerland, finally qualifying at the National School of Fine Arts in Rio de Janeiro. He founded a partnership

\footnotetext{
${ }^{6}$ For example 'The International Style' by Russell and Hitchcock in 1932.
} 
with a Ukrainian architect, Gregori Warchavchik (1896-1972), who was influenced by the Futurists and Modernists he had studied in Odessa and Rome. Costa designed the 1939 New York World's Fair Brazilian pavilion in association with Oscar Niemeyer and Paul Lester Wiener (18951967). Here all of the elements that would guide a Brazilian third Modern Movement were already present; pilotis, organic garden and grid-like façade providing privacy for offices and service spaces.

It was in Brazil that the orthodoxy of Le Corbusier found a new life through the adaptation of his principles by architects such as Lúcio Costa and his protégé Oscar Niemeyer (CHIPKIN, 1993, p. 230). Le Corbusier's visit in 1937 must have been instrumental in this regard as it fostered a regional variation of his theories particularly through the development of the brise-soleil first proposed by Le Corbusier, through horizontal moveable shutters in an unbuilt housing scheme for Barcelona in 1933 (GOODWIN, $1943 a$, p. 84). "From the ' 30 s to the ' 50 s, before the widespread use of mechanical HVAC systems, the brise-soleil operated on these terms as a techno-cultural object able to mediate a variety of climatic conditions" (http://www.academia.edu/10112316/Le_Corbus ier_The_Brise-Soleil_and_the_Socio-

Climat-

ic_Project_of_Modern_Architecture_19291963). Goodwin also notes (1943b, p. 10) that "Brazil's great original contribution to modern architecture is the control of heat and glare on glass surfaces by means of external blinds".

\section{Modern Movements in the Union of South Africa}

The first rumblings of an inherited (second) Modern Movement in South Africa were recorded by Stanley Furner (1892-1971) when he became head of the Witwatersrand School of Architecture (Wits) in 1925 and editor of the South African Architectural Record (SAAR) in 1926. His publication 'The Modern Movement in South Africa' was, according to Herbert (1967, p. 26), a seminal piece for the future of architecture as it expressed a clear understanding of the logic and philosophy of modernity, steering skilfully clear of issues of style and aesthetics.

Thereafter the limited influence of a transitory modernity on domestic architecture in South Africa in the 1930s (CURTIS, 1996, p. 306) was pioneered by Rex Distin Martienssen (19051942) who qualified from Wits in 1930. Martienssen's direct contact with Le Corbusier paved the way for the distillation of Modern Movement tenets mainly in the Transvaal ${ }^{7}$, after he had taken over the editorship of the SAAR in 1932. Together with a small band of like-minded protagonists, Gordon McIntosh (1904-1983) and Norman Hanson (1909-1991) (later referred to as the Transvaal Group) Martienssen forged an alliance that led to the publication of zero hour on 1 April 1933 (GERNEKE, 1998, p. 209). This manifesto proclaimed the virtues of a new technologically and functionally driven architecture and was widely disseminated, even directly to Le Corbusier. It was well received by him, who published the letter he wrote to Martienssen in the introduction to his 1936 Oeuvre Complète (1919-1929).

But the limited orthodox Modern Movement influence waned during the Second World War. Herbert indicates (1975, p. 28) that the affection for the English house was still important at Wits during the early 1940s and after the untimely death of Martienssen in 1942, counter-classical trends and the beginnings of a nationalist fervour looked elsewhere for inspiration. A modernregionalism slowly developed (BARKER 2012, p. 84).

The third Modern Movement in the Union of South Africa mediated the effects of local climate with limited post-war resources and canonic principles of spatial and structural efficiency. It developed in the decade after the war $^{8}$, where the new generation of architects, now freed from the compulsions and fuddy-duddiness of Dutch or British colonial traditions, turned, not to the dominant Corbusierism of the Wits School or its subsequent angst-ridden debates, but to a new

\footnotetext{
7 The Province of the Transvaal, commonly referred to as the Transvaal Province, or just the Transvaal, was a province of South Africa from 1910 until the end of apartheid in 1994.

8 The Second World War.
} 
source of nation-building, partly state-promoted modernity of the architecture of post-war Brazil (CHIPKIN, 1993, p. 279).

\section{Identity, climate and efficiencies}

The search for a new architectural identity in the Union of South Africa (and specifically Pretoria) was spurred on, not only, by reactions to stagnant architectual traditions and Modern Movement canon but also technological failures, poor climatic responses, the establishment of new local industries and the inauguration of the new Nationalist party government in 1948. Even before this, a debate about Dutch and British colonialist styles raged on for months in various publications and exhibitions ${ }^{9}$ in South Africa. Its focus was clearly articulated expressed by a student who exclaimed:

I am sure that the only way in which a real style is evolved is by unconscious effort. A clear logical attempt to solve local problems will in the course of years result in a real South African tradition and not a forced and consequently deformed style ... it is only in the logical solution of your own programme in the light of past experience that you can find hope for the future (HERBERT, 1975, p. 22).

The residue of the Modern Movement leanings of the zero hour group was clearly evident in the post war commericial boom in Johannesburg. Many apartments and office blocks were constructed in the Le Corbusier idiom compete with pilotis and large single sheet glass windows and roof gardens (CHIPKIN, 1993, p. 169).

In contradiction, the architecture of Pretoria in the 1940s and 1950s was more versatile and adaptable than its orthodox Johannesburg counterpart (HERBERT, 1975, p. 152). Pevsner (1953, p. 211) comments, in the journal Architectural Review in 1953 that this tendency "clearly points to what can be done to free official architecture from the heavy hand of convention and outmoded tradition". Fisher (PRINSLOO, 2000, p. 96) indicates that the prerequisites for a regional style were all present

\footnotetext{
${ }^{9}$ For example an Art of Architecture exhibition held in September 1947 at Wits and publications in the SAAR (see Cooke, 1998,p. 232).
}

in Pretoria during the 1940s and 1950s: graduates fresh from a pragmatic education, state commissions to further nationalism after the election of the National Party in 1948, an improved patronage of the modern aesthetic and a rich diversity of indigenous building materials.

The time was ripe for new influences and the 1943 Museum of Modern Art (MOMA) exhibition and subsequent publication of "Brazil Builds" brought new Modern Movement mutations to the rest of the world, including South Africa. Prior to this publication, newspaper articles had also highlighted the new developments while Chipkin (1993, p. 231) notes that prof. Pearse of Wits owned an early copy of "Brazil Builds", dated 1944. The 1950 monograph on Niemeyer by Papadaki (DE BEER, 2000, p. 110) added impetus to the advantages of employing South American adaptations in the Transvaal climate. Fagan $^{10}$ (1925-) suggests (2008) that the affinity of the Afrikaner ${ }^{11}$ for the language of Portugal and thus the South Americas played a role in this interpretation.

A number of South African architects, such as Norman Eaton, Barrie Biermann (GERNEKE, 2014, p. 41) and the President-in-Chief of the Institute of South African Architects (ISAA) Brodrick St Clair Lightfoot (1905-1970), visited Brazil. Fassler (1956, p. 178) notes that the Brazilian influence could later be seen in the work of Philip Nel and Partners, and Meiring and Naudé of Pretoria and Cape Town. Stauch's visit to Brazil at the end of 1948 directly inspired his design of the Meat Board building in Pretoria (CHIPKIN, 1993, p. 282). "Pretoria became a 'Little Brazil', a style term used by Chipkin (1993) derived from Pevsner's (1953) observation that Johannesburg was 'a little Brazil' within the Commonwealth" (http://www.artefacts. co.za/main/Buildings/style_det.php?styleid=70).

The drive for a new "honest" architectural identi-

\footnotetext{
10 Gabriël (Gawie) Fagan is South Africa's most awarded architects. He trained at the University of Pretoria (19471951) under Hellmut Stauch and other regional-modernists and developed a unique architectural vernacular in the Cape region of the country that mediates the third Modern Movement and Dutch vernacular (see Barker, 2012).

${ }^{11}$ The Afrikaner is a name given to the group of descendants of Dutch colonialists that developed their own language and settled in South Africa after 1652.
} 
ty was spurred on by the new school of architecture established at the University of Pretoria in 1943. The products of the students were innovative and contextually appropriate through their direct association with place through material usage and climatic response which created an honest and pragmatic response to pressing needs (BARKER, 2012, p. 88).

The Pretoria students were beginning to "... draw diagrams analysing sun-angles for the north facade. [Architects] favoured local materials: stone from the koppies $^{12}$ and bricks for walls and floors (NATION, 2003, p. 2). The "form follows function" principle dominated and this married very well with the frugal approach thrust upon us all by general post-war shortages (NATION, 2008, p. 9). As Tzonis (2007, p. 216) has remarked, the architects of this time were focussed on "advancing efficiency of construction and enhancing comfort".

The aesthetic and canonic goals of the Transvaal Group could not be met by available technologies in the harshness of the local climate. Herbert (1975, p. 234) describes the building industry in the 1930s in South Africa as archaic, as there was little mechanization on site, very few building components were being produced by industry, and the small labour force was biased towards a craft building approach. There was a serious incongruity between the technical needs of the new movement and what could be supplied. This issue prompted a move towards an architecture that synthesised the use of simpler and more widely available materials and technologies with modern needs.

Perhaps the most significant event which was to influence the growth of Pretoria was the establishment of the South African Iron \& Steel Corporation Ltd. (Iscor). The position of Pretoria as an industrial town was confirmed and with the growth of steel came the growth of secondary industry - Pretoria grew out of infancy into adolescence (MCINTOSH, 1956, p. 22). Iscor was established in 1928 after a governmentpromulgated act which saw the government

12 This is Afrikaans (a South African language developed from Dutch) which means hills. owning $99 \%$ of the shares due to a lack of public interest (MULLER, 1984, p. 418). Until then, most standardized building products were sourced from overseas (ANON, 1965, p. 38), save for the brick provided by the Kirkness factories.

In 1936, Iscor (ANON, 1965, p. 38) ${ }^{13}$ began producing steel roofing sheets and standardized steel windows on a 3'4" module. These were to become part of the Pretoria regional aesthetic through the work of architects like Stauch (PETERS, 1998, p. 185) and Robert Cole Bowen (1904-1976) (FISHER, 1998, p. 132). The modules developed a particular aesthetic but also assisted in the development of a structural logic. Steel roof sheeting was economically and climatically advantageous as it allowed for lower roof slopes, larger overhangs and limited roof structure. The necessity for the industrialization of architecture highlighted the mediative condition that many Pretoria architects were to employ. 'Old' materials did not have to be discarded; they just needed to be used in a 'modern' way.

Spatial economy was also a major concern of the time. Hellmut Stauch used the monopitch, as he believed the 'pitched roof combined with a flat ceiling wasted valuable space' (NATION, 2003, p. 2). Cooke (1993, p. 30) notes that Roy Kantorowich (1911-1976) was critical of the Corbusian spatial system which created wasteful and awkward spaces through the structural separation of wall and column. Plans were often organized to limit circulation space, with most relying on a central entry point or movement through dining spaces as can be seen in the economic plans of Cole-Bowen (ANON, 1953b, p. 36-49), whose work Fassler (1956, p. 178) describes as attractively economical with a clear rationale. Farther economic effiency was emplyed in the use of materials in their natural" state. With the exception of the kitchens there are very few applied internal finishes, the principle followed being that anything built is final. No second or third processes are needed.

A third Modern Movement mediation was estab-

\footnotetext{
${ }^{13}$ Fisher (1998, p. 131) notes 7 May 1937.
} 
lished and its principles would have a long lasting effect on the architectural of Pretoria after the Second World War. One of its major proponents was the German immigrant Hellmut Stauch.

\section{Hellmut Stauch}

Hellmut Stauch was born on 10 March 1910 in Eisenach, Germany. His father was involved in the diamond industry and spent much time in South West Africa (SWA) ${ }^{14}$. At the age of two the family moved to Zehlendorf in Berlin where Stauch developed a life-long affinity for sailing ${ }^{15}$ (NATION, 1985, p. 3). This probably influenced his thinking on spatial and formal efficiency in architecture in line with Le Corbusier's dictum that reconsidered the relationship between form and function.

Stauch's architectural training was undertaken at the Itten-Schule in Berlin from 1926-1929, instigated by his sister's attendance. His technical training was undertaken at the Technische Hochschule in Berlin (NATION, 1985, p. 11). Here some of his student work demonstrates the early investigations into solar orientation (Nation, 1985, p. 26). After Stauch's father's business ventures came to an abrupt end, Stauch's father sold up everything in Germany and moved to SWA leaving the children behind to finish their studies.

In 1929 Stauch accepted "an offer by the SWA Farming and Trust Company for the design of various farm and office buildings in the Windhoek district and had spent some months on this project. At this time he was still a student, under Forbat, at the Itten-Schule" (Nation, 1985, p. 28). Herbert (1975, p. 150) notes that the domestic buildings he designed on the family farm at Dordabis were structurally rational and modular with continuous bands of windows in the Bauhaus fashion.

Stauch then returned to Germany to get married and his wife soon gave birth to a daughter. Stauch was only 19. He was forced to work to make ends meet and found favour with Fred

\footnotetext{
14 Now known as Namibia.

15 Stauch would eventually achieve national sailing honours in South Africa.
}

Forbat (1897-1972), (who had been his lecturer at the Itten Schule) and Wilhelm Peters while assisting Walter Gropius and Marcel Breuer (1902-1981) on housing schemes (NATION, 1985, p. 28, PETERS, 1987, p. 23, HERBERT, 1975, p. 150). Around 1932 he divorced his wife and she, with her new husband, moved to Brazil, a country that Stauch would visit in 1948.

Stauch decided to leave Germany permanently, probably due to the proscription on modern architecture after a regime change, the depressed economy and the closure of the Itten-Schule (PETERS, 1987, p. 23) but he did not join his family in Windhoek rather arriving in Cape Town, South Africa in 1934 (NATION, 1985, p. 43). Work prospects were bleak in the Mother City and Stauch moved to Pretoria on March 24th 1935 and joined Aubrey Nunn (1905-?) in his practice. Stauch was also a partner of F.J. Wepener, thereafter opening his own practice (NATION, 1985, p. 1). He also taught at the newly established Department of Architecture at University of Pretoria, beginning his eight year tenure in 1943 (NATION, 1985, p. 61).

The Rousseauian philosophical direction of the Itten-Schule distinguished it from the Bauhaus' more direct relationship with industry. It therefore represented a less radical or revolutionary approach to the making of architecture, aligning itself more closely with the Arts and Crafts direction of earlier architects working in Pretoria such as Herbert Baker (1862-1946), Gordon Leith (1886-1965) and Norman Eaton (1902-1966). Not unlike the Bauhaus trained architect Pius Pahl (1909-2003), who worked in the Cape, Stauch managed to synthesise his European training with local circumstances to achieve a unique synergy between modernity and tradition. But Stauch's German training was perhaps an already mediated modernity (BARKER, 2012, p. 101) as

a common feature of Modernist houses in
the 1930s was the use of natural flagstones
which ran uninterrupted from exterior veran-
da to interior living room. Architects discov-
ered that they could reap the benefits of us-
ing natural materials - brick, stone and wood
- while still introducing the open spaces and
generous expanses of glass which demon- 
strated the separation of structure from enclosure and which defined Modernism in architecture (BENTON, 2006, p. 87).

Stauch's architecture of the 1930s had a longlasting effect on the domestic architecture of Pretoria. His "rectangular plans, oriented due north...structure[d] and manipulate[d] space in the Miesian manner [while] seek[ing] for contact between interior and exterior" (PETERS, 1998, p. 176). "His domestic work exhibited a light and sensitive interpretation of standardised components, reminiscent of the philosophy of Neutra" (NATION, 1985, p. 109).

In 1943 Philip Goodwin (1943b, p. 10) exclaims that "Rio de Janeiro has the most beautiful government building in the Western Hemisphere, the new Ministry of Education and Health Building". This influential Brazilian building was visited by Stauch at the end of 1948 (HERBERT, 1975 , p. 279). The first design was completed in 1936 and Le Corbusier was invited in July 1936 to review the finished proposals. After he designed another scheme on a different site the final solution was arrived at and construction began in 1937 on the original plot of land in the heart of Rio de Janeiro.

Two perpendicular blocks on reinforced offshutter concrete pilotis define an open public plaza at ground level articulated by the landscape architect Roberto Burle Marx. Complete with organic roof gardens and a separate auditorium space the north facing tower block was shaded by a unique egg crate façade ${ }^{16}$ of manually adjustable blue horizontal steel framed fibre cement louvres. The southern façade was constructed of double-hung sash unshaded windows. Traditional Portuguese blue and white mosaics articulate important elements.

Stauch evidently travelled to Brazil with the express intention of meeting Oscar Niemeyer ${ }^{17}$. The visit "surprised him in many ways. Although he had a deep admiration for the South American architect, Niemeyer's disregard for such practicalities as whether or not the roof leaked came as a shock to Stauch. But Niemeyer's

\footnotetext{
${ }^{16}$ The first of its kind according to Goodwin (1943, p. 106)

17 One can also assume it was to visit his daughter and possibly due to family connections (Herbert, 1975:279).
}

emphasis on aesthetic values appears to have appealed to him strongly; it was to a large extent dominant in his own architectural philosophy" (NATION, 1985, p. 67).

"Oscar Niemeyer struck him as being very similar to Marcel Breuer... of Niemeyer Stauch said 'He is a very gifted, brilliant artist for whom expression and form is almost everything. We were in Rio de Janeiro in 1948 when this book "Brazil Builds" had just been published and we especially went to look at the various jobs mentioned in this book and when we went to the addresses we could hardly find the buildings because, what in the photograph was a beautiful white, sharp, clean job, now has streaks of grey, rust and brown over it and cracks and creepers are growing and corrugated iron lean-to roofs were attached in front to shade the façade and this is just one extreme case but there were quite a number of these. We then met Oscar Niemeyer and asked him about his views. He said that it is not very important how buildings looked after ten years, it is important what impact they make initially"' (NATION, 1985, p. 106,107).

\section{The Meat Board Building, Pretoria}

The aftermath of the 1948 election and the onset of Nationalism in the Union of South Africa brought with it the search for a new architectural identity, particularly in Pretoria. The impetus was twofold. Firstly, a new identity could downplay colonialist and classicist architectural tendencies which were at the core of the city's architecture while, secondly, quasi government institutions could express their uniqueness in a new industrial age with new functional requirements.

The Meat Board was a semi-government organisation in need of administrative accommodation in a residential area in Pretoria. Stauch was the man for the job armed with new Brazilian precedent. He was also, by now, a nationally recognised architect with a sensitive local take on international Modern Movement traditions. The resulting architecture displayed a new, powerful architectural identity firmly rooted in place through its climatic and technological allegiances and negation of classicist and colonialist for- 
mal tendencies.

Hellmut Stauch, in a synthesis of the new Brazilian architecture, produced the first South African civic building in the Moderrn Idiom, and one of a high architectural standard at that (GERNEKE, 1998, p. 216).

International critics such as Nikolaus Pevsner were equally impressed with the Meat Board Building. In his analysis in the journal Architectural Review he notes that "we are privileged to review in these pages an outstanding building which was recently completed for the Meat Board in Pretoria...it makes a most valuable contribution to the limited range of buildings in this class" (PEVSNER, 1953, p. 211). The architect's work was clearly already internationally established as, for example, Sir Hugh Casson's article on South Africa in the 1940 Architectural Review "gave over the cover story to Stauch's work" (PETERS, 1987, p. 29). Later, the American publication Architectural Forum devoted a section on the building in its February 1953 edition, referring to Stauch's design as "Modular Office Building".

Figure 2: Scale model of the Meat Board Building, Pretoria, 1952.

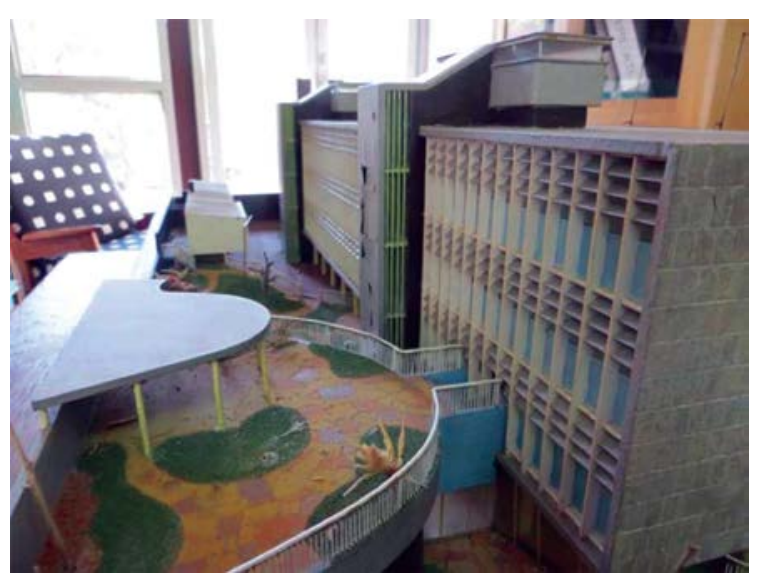

Font: Fisher, 2013.

The Meat Board required a signature building that could house flexible office spaces, a boardroom for fifty people with a separate foyer and services, a reading room and two small, separately accessible, meeting rooms that could be combined into one. Storage spaces for the delivery of paper, a caretaker's apartment and servant's quarters and a garden were other requirements (HOWIE, 1952, p. 212).
The tight, $65.2 \mathrm{~m}$ by $32.6 \mathrm{~m}$, site ${ }^{18}$ with a $2.5 \mathrm{~m}$ fall from east to west and a three floor height restriction required clever manipulation of by Stauch. By exaggerating the existing slope, and raising the structure on yellow painted concrete pilotis, he provided an additional floor (see Figs. 3 and 7). But this formal recall of Le Corbusier's orthodoxy unfortunately only provided adequate parking under the building and not an accessible public space as in the Ministry of Education and Health Building.

Figure 3: Lower ground floor level showing access, parking and garden.

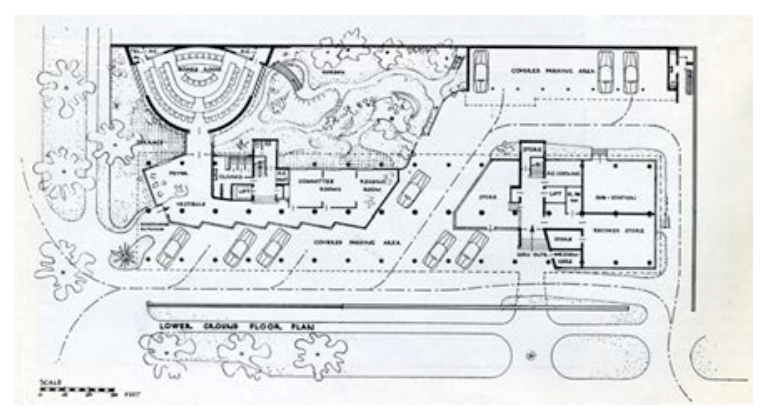

Font: Howie, 1952, p. 214

The main, north oriented, building form and functional and formal separation of the auditorium space, closely recall the Brazilian precedent and are appropriate for the context of Pretoria and the client's program but the organic BurleMarx inspired roof and ground floor gardens are not, necessarily, suited to the landscape of Pretoria. Other appropriate formal similarities are the solid western (see Fig. 4) and eastern ends and articulation of stairwells on the eastern end and on the roof extended vertically on the north façade of the Meat Board building.

Stauch reinterpreted Niemeyer's articulation of walls (through traditional Portuguese mosaic murals in the Ministry of Education and Health Building) with plain geometric blue glass mosaic panels, on terrazzo cladding, under glazed windows (see Fig. 4). Due to its location on the upper ground level, a concrete framed entrance had to be constructed to articulate the entrance (see Fig. 7) (unlike the pilotis of the Ministry of Education and Health Building) and is, more closely, connected to Le Corbusier's Clarté ex-

18 The site is on the corner of Hamilton and Vermeulen Streets, Pretoria, South Africa. Latitude: $-25.743334^{\circ} \mathrm{S}$ and longitude: $28.206321^{\circ} \mathrm{E}$. 
periment. In line with Stauch's predilection for differentiating between structure and enclosure, the concrete framed box tying the upper three floors together (as well as the steel columns) are clad in terrazzo.

Stauch's early experiments with climate control through eastern orientation and recessed porches on the western facade in the severe Windhoek climate were proved incorrect and he later opted for a northerly orientation for his buildings. But it was this work that set the scene for his later domestic solutions in Pretoria using roof overhangs to control sun penetration. He carefully calculated these to provide winter sun penetration and summer exclusion. Stauch's solution of adjustable horizontal louvers on the northern façade of the Meat Board Building belie these formative influences as the three panels (see Fig. 1) demonstrate little invention from their Brazilian precedent but the vertical mullions on the southern façade "screen the offices from the slanting rays of the sun - an important factor even on the south elevation in Pretoria" (PEVSNER, 1953, p. 215) - not used in the Ministry of Education and Health Building. Glazed panels also vary in size being shallower on the north façade of the Meat Board Building as a direct response to the harsh summer climate. On account of the latitude, southern facing windows are deeper.

Figure 4: Top left: West façade

(http://wiki.up.ac.za/index.php/File:Meat5.jpg). Top right: South western corner (author, 2008). Bottom: Ground floor entrance level plan.

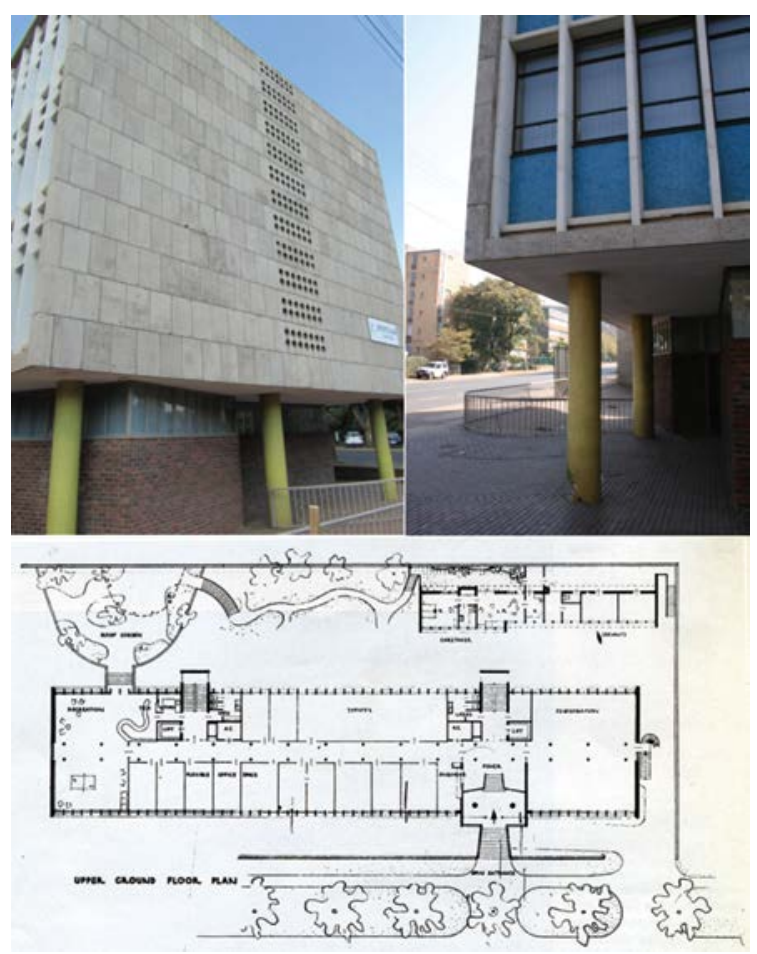

Font: Howie, 1952, p. 218.

Stauch's investigations into structural and spatial efficiency were initiated in the 1930s while working with Peters Bau in Germany performing the role of consultant on housing. There Stauch "developed an appropriate philosophy of 'core housing'...It utilized an industrial system, was based on a two-directional module of $1050 \mathrm{~mm}$ and its plan forms 'were a great deal more acceptable and liveable than those of many industrialised buildings in production today'.

Stauch's early sojourn to Windhoek in 1934 (HERBERT, 1975, p. 151) to design farm buildings for the S.W.A. Farming and Trading Company ${ }^{19}$ and his earlier domestic architectural investigations in Pretoria developed these approaches he realised the potential of internal spatial flexibility through modularity. "As far as the house itself was concerned he especially held to the concept of a changeable dwelling fitted to current usage. He stated that 'every shape of usage develops into a perfect shape and this should be the basis for all further development"' (NATION, 1985, p. 105). Hochstetter House was unique in that it was probably the first building in Pretoria, if not South Africa, to

\footnotetext{
19 These were published in (unidentified) German magazine (Neues Bauen in den Kolonien von Architekt Hellmut Stauch, 1935) (Nation, 1985, p. 104).
} 
express totally the concrete frame and infill panel of which it was constructed. It was modular in design, well proportioned and precisely detailed" (NATION, 1985, p. 46).

Figure 5: Stauch's structural solution for the Meat Board Building.

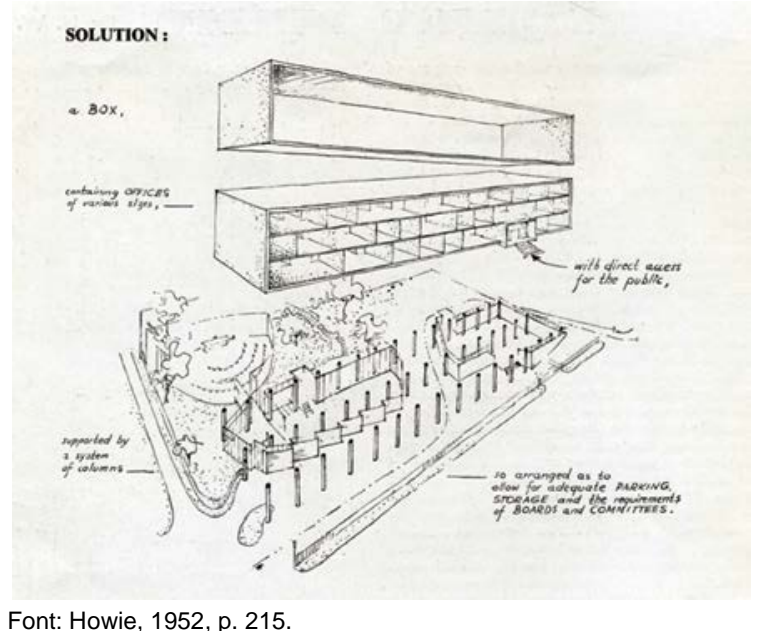

Stauch's modular approach reached a climax in the Meat Board Building (see Fig. 3). It was designed on a 1041 (3' 5") module which facilitated adequate office sizes ( 3 modules wide) and doorways ( 1 module). The module provided a rhythm of structural expression while framing the north facing precast vertical and horizontal sunshades (ANON, 1953a, p. 148). It farther allowed timber framed and asbestos lined office partitions to be moved at will (see Fig. 6).

The concrete framed structural system (see Fig. 5) "is a composite construction of ribbed concrete floors, supported by pairs of concrete columns, space four times the module along the centre, which also supports the dropped slabs, containing air-conditioning ducts and other services by R.S.J. supports along the external walls" (ANON, 1952, p. 55).

The piloti system only on the lower floor allowed for complete planning flexibility on the upper three floors and mitigated the criticism of awkward resultant spaces between structure and enclosure (see section at fig. 6) in the Ministry of Education and Health Building. The parking system was diagonally organised to facilitate easy access and egress recalling a similar organization at Villa Savoye.
Figure 6: Detail section of façade (HOWIE, 1952, p. 218) and interior perspectives of spatial flexibility.
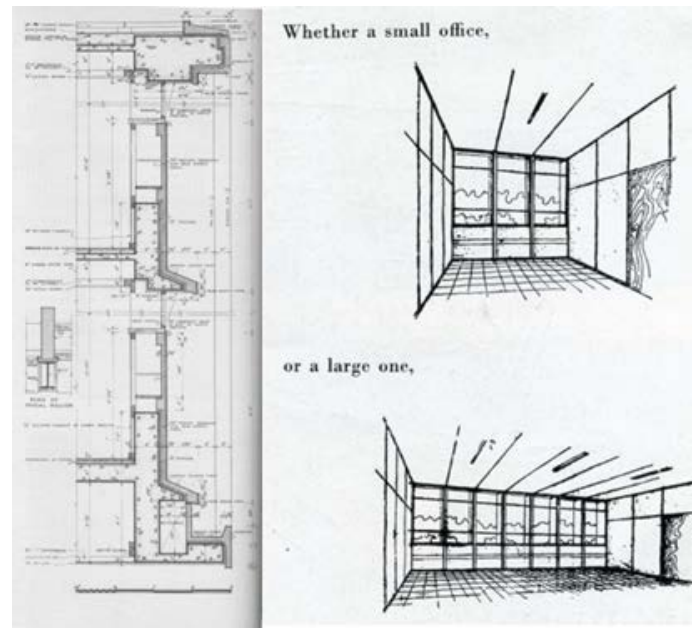

or a large one,

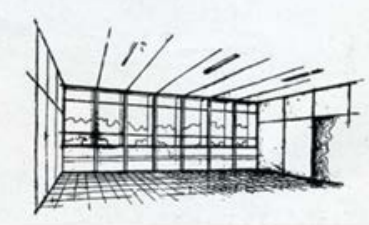

Font: Howie, 1952, p. 215

Figure 7: Top: Entrance level plan. Bottom: North and South elevations and section looking west.

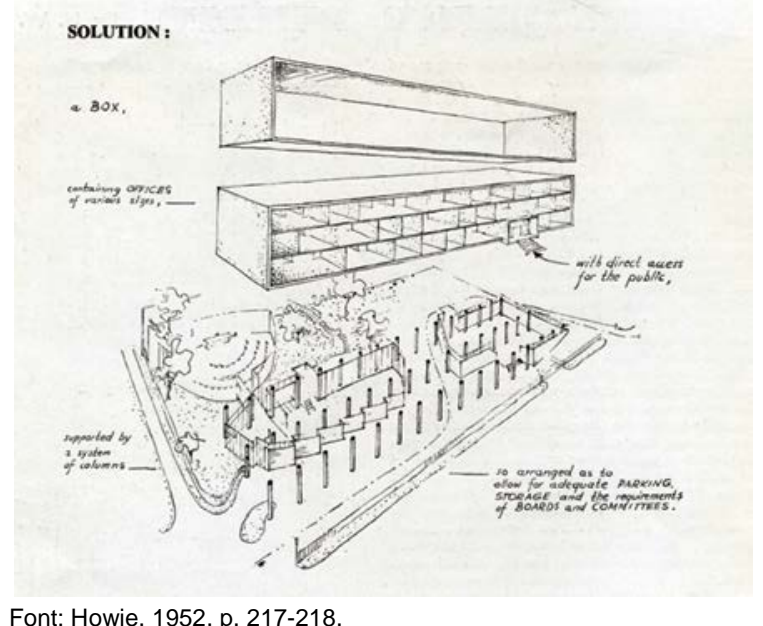

\section{Conclusion}

Mediations, throughout the world, of Modern Movement canon and initial orthodoxy resulted in cultural and climatic architectural mediations. This was none more so than in Brazil and South Africa. The Brazil Builds publication and visits by a number of South African architects to that country resulted in an iconic and trend setting third Modern Movement mediation in the Union of South Africa. Hellmut Stauch's Meat Board Building completed in 1952 in Pretoria, exemplified the search for a new architectural identity that dispelled with colonialist influences. It built on precedent already established in Johannesburg but was a tour de force in architecture in the Union at the time, through the conscious effort of Stauch to deal with climatic issues and 
constructional and spatial efficiencies.

Today the building (now named Nipilar house) still stands proudly as a testament to the legacy of an innovative and principled architect whose Modern Movement training was extended by the exigencies of place and functional and technological efficiencies. The building is older than sixty years and is thus protected by Section 34 of the South African National Heritage Resources Agency (SAHRA) Act 25 of 1999. After the building was given a design award in 1956, an agreement reached between owner and SAHRA has limited the impact of minor changes over time ${ }^{20}$. These have not affected the building's overall character and its architectural strengths still serve as inspiration for climatic and constructional identity.

The Meat Board Building established a benchmark for other public buildings such as the Aula and Rautenbach Hall (on the campus of the University of Pretoria) by Philip Nel and Partners (1958) (CLARKE, 2011, p. 26), the South African Broadcasting Corporation (SABC) building in Sea Point (1955) by Meiring and Naude and the Transvaal Provincial Administration (TPA) Building (1962) by Meiring Naude Moerdijk Watson. Even the, relatively new, 2012 Engineering III building on the University of Pretoria's Hatfield campus features appropriately located sunscreens paying homage to its neighbour, the 1958 Musaion and Amphitheatre Building, by Brian Sandrok (1925-1990). Although fashions come and go, the power of the third Modern Movement in South Africa, through its Brazilian heritage, still has influence in Pretoria today.

\section{References}

ANON. Historical scene. South African Architectural Record, December, p. 24-69, 1965.

ANON. Meat Board Building, Pretoria. Architect and Builder. September, p. 54-61, 1952.

ANON. Modular office building. Architectural Forum, February. p. 146-149, 1953a.

ANON. Three Pretoria Houses. Architect and Builder, April, p. 34-49, 1953b.

\footnotetext{
${ }^{20}$ None of the gardens exist today.
}

Barber. D. Le Corbusier. The Brise Soleil and the Socio-Climatic Project of Modern Architecture. Retrieved from <http://www.academia.edu/10112316/Le_Corbu sier_The_Brise-Soleil_and_the_Socio-

Climatic_Project_of_Modern_Architecture_1929-1963> [Accessed 16 March 2017].

BARKER, A. Heterotrophic syntheses: mediation in the domestic architecture of Gabriël (Gawie) Fagan. Pretoria: Unpublished PhD, University of Pretoria, 2012.

BENTON, T. The Modernist House. London: V\&A Publications, 2006.

CHIPKIN, Clive M. Johannesburg Style: Architecture and Society 1880s - 1960s. Cape Town: David Philip, 1993.

CLARKE, N. Architectural history of the capital. In Matthews, P.J. (ed.). Contemporary capital: an architectural journal. Pretoria: Visual Books, 2011.

COOKE, J. A biographical history: Helmutt (sic) Stauch. In Beck, H. (ed.). UIA International Architect: Southern Africa, (8), p. 61, 1985.

COOKE, J. Revisions of the Modern. In Architecture of the Transvaal. Edited by R.C. Fisher \& S. le Roux with E. Maré. Pretoria: University of South Africa, 1998, p. 231-251.

COOKE, J. Shifts after the Thirties. Architecture South Africa, (7/8), July/August, p. 23-30, 1993.

CURTIS, W. Modern Architecture since 1900. London: Phaidon, 1996.

DE BEER, I. Brazil. In Architecture 2000. Edited by I. Prinsloo. Johannesburg: Picasso Headline, p. 109-110, 2000.

FAGAN, G.T. \& G. Interview with the author on 26 March 2008. 156 Bree Street, Cape Town, 2008.

FASSLER, J. Contemporary Architecture in South Africa. Architectural Design. June (6), p. 176-179, 1956.

FISHER, R.C. The Third vernacular. Pretoria Regionalism - aspects of an emergence. In Architecture of the Transvaal. Edited by R.C. Fisher \& S. le Roux with E. Maré. Pretoria: University of South Africa, 1998, p. 123-147. 
GERNEKE, G. Oscar Ribbeiro de Almeida Niemyer Soares Filho (1907-2012). Architecture South Africa. Issue 65, Jan/Feb, 2014, p. 39-45.

GERNEKE, G. From Brazil to Pretoria - The Second Wave of the Modern Movement. In Architecture of the Transvaal, First edition, edited by R.C. Fisher, S. le Roux \& E. Mare. Pretoria: University of South Africa, 1998, p. 216-217 \& 224 ill.

GHIRADO, D. Architecture after Modernism. Thames \& Hudson, 1996.

GOODWIN, Philip L. BRAZIL BUILDS. Design; Mar 1, 44, 7; Periodicals Archive Online, p. 10, 1943b.

GOODWIN, Philip L. BRAZIL BUILDS. Museum of Modern Art, New York, 1943a.

HERBERT, G. Martienssen and the International Style: the modern movement in South African Architecture. Cape Town: A.A. Balkema, 1975.

HEYNEN, H. Architecture and Modernity. Cambridge: MIT Press, 1999.

HOWIE, W.D. 'The Meat Board building, Pretoria'. South African Architectural Record, September, p. 212-222, 1952.

JENCKS, C. Modern Movements in Architecture. Garden City, N.Y: Penguin, 1985.

JOEDICKE, J. Architecture since 1945. London: Pall Mall, 1969.

Lexicon. Little Brazil. Artefacts. 2017. Retrieved from.

http://www.artefacts.co.za/main/Buildings/style _ det.php?styleid=70 [Accessed 14 March 2017].

MCINTOSH, W.G. Pretoria's architecture: present and future. South African Architectural Record, May, p. 22-23, 1956.

Meat Board Building, 140 Hamilton Avenue, Arcadia, Tshwane. Ablewiki. 2010. ABLEWIKI:NipilarHouse. Retrieved from $<$ http://wiki.up.ac.za/index.php/ABLEWIKI:Nipilar House> [Accessed 14 March 2017].

MULLER, C.J.F. Five Hundred Years - A history of South Africa. Pretoria, Cape Town: Academica, 1984.

NATION, S. The background, architectural philosophy and work of Hellmutt Wilhelm Ernst
Stauch. Unpublished Master's thesis. University of Pretoria: Pretoria, 1985.

PETERS, W. Houses for Pretoria. In Architecture of the Transvaal. Edited by R.C. Fisher \& S. le Roux with E. Maré. Pretoria: University of South Africa, 1998, 175-195.

PETERS, W. The importance of the '30s in the Domestic Architecture of Hellmut Stauch. Architecture South Africa, January/February, p. 2329, 1987.

PEVSNER, N. Johannesburg: Meat Board Building. The Architectural Review. Vol. 113. Number 678. June, p. 375, 1953.

PRINSLOO, I. (ed.). Architecture 2000: A review of South African Architecture. Johannesburg: Picasso Headline, 2000.

SILVERMAN, M. 'Ons bou vir die Bank': Nationalism, architecture and Volkskas Bank' in Blank, Architecture Apartheid and After. 1999, p. 129143.

ST. JOHN WILSON, C. The other tradition of Modern Architecture - the uncompleted project. London: Blackdog, 2007.

STAUCH, H.W.E. 'A modern office building'. REPRINT: Public Works of South Africa, July p. 1-8, 1951.

STAUCH, H.W.E. The double lean-to roof or house planning from a different angle. South African Architectural Record, 30, p. 207-13, 1945.

The Meat Board Building. Artefacts. 2017. Retrieved from <http://www.artefacts.co.za/main/Buildings/bldgf rames.php?bldgid $=127>$ [Accessed 14 March 2017].

TZONIS, A. Thoughts on South African Architecture Today. Digest of South African Architecture. 11 , p. 216-218, 2007. 